\title{
Assessing the Effect of Foreign Direct Investments on the Performance of Manufacturing Subsector in Nigeria
}

\author{
EGBERI, Agbarha Kelvin P.hD \\ Department of Business Administration and Management, Delta State Polytechnic, Ozoro \\ Helen E.O. Lucent-Iwhiwhu \\ Department of Business Administration and Management, Delta State Polytechnic, Ozoro
}

\begin{abstract}
This paper has been on assessing the effect of foreign direct investment on the performance of manufacturing subsector in Nigeria. Ex-post facto research design was utilized and foreign direct investment, average manufacturing capacity utilization and oil and refining, cement and other manufacturing subsector performance measures were obtained from the Central Bank of Nigeria (CBN) Statistical Bulletin and World Bank Development Indicators during the period 1981 to 2016 . The data were analysed using stationarity and unit root test, co-integration, parsimonious error correction model, and granger causality tests. The result indicates that foreign direct investment and average manufacturing capacity utilization were not statistically significant in explaining the changes in oil and refining firms contribution to the sector. Contrarily, it was established that foreign direct investment was statistically significant in explaining other manufacturing firms' contribution to the sector. The result overall indicates that policies to attract foreign direct investment if well managed could improve the manufacturing subsector performance in Nigeria. On the basis of this, it was recommended among other that the government should deepen their efforts to open up the manufacturing subsector to foreign direct investments. This will reduce the dominance of a particular company in the sector and further improve the output of the manufacturing subsector.
\end{abstract}

Keywords: Foreign direct investment; manufacturing performance; economic growth

DOI: $10.7176 / \mathrm{EJBM} / 11-35-02$

Publication date: December $31^{\text {st }} 2019$

\section{Introduction}

In recent years, Nigeria has attained some considerable level of economic growth. Some factors seem to have played a role in this success story of the Nigerian economy. Fundamental among these factors include the swift development in liberalization of trade and significant increase in foreign capital influx into the nation (Olaseni, 2017). Oji and Huang (2016) have argued that Foreign Direct Investment (FDI) is one of the utmost fundamental dynamics for the promotion of economic development and growth in most countries of the world. FDI is viewed as a mechanism of economic growth in developing nations by augmenting opportunities for globalization, capital flows, technology transfer which is usually termed as "spillover effect", enlargement of employment and export opportunities which augment the potential of host nations.

Most countries strive to attract FDI in the manufacturing sector because of its recognized advantages as a means of economic development. Most Africa nation and Nigeria in particular joined the rest part of the world to seek foreign capital as corroborated by the establishment of New Partnership for Africa's Development (NEPAD), which has helped in the magnetism of foreign investment to most Africa nations including Nigeria. Improvements in economic policies are desired to promote macroeconomic performance and realize the least possible growth rate needed to sustain the Millennium Development Goals (MDG) established by the United Nations (UN). An increase in investment is crucial to the actualization of sustained development and growth in the nation. This demands the mobilization of both international and local finances. Given the instability of foreign aid flows, the low share of the nation in world trade, the high variation of short-term capital flows, and the low savings rate of the nation, the desired increase in investment has to be attained via an increase in FDI inflows, at least in the short-run.

Until recently, FDI was not fully embraced by Nigeria and other African countries as an essential feature of growth in the manufacturing sector, reflecting largely fears that it could result to loss of political sovereignty, push domestic firms into bankruptcy as a result of increased competition and, if entry is prevalent in the natural resource sector hasten the risk of environment degradation. Akinlo (2006) maintains that much of the skepticism toward FDI is entrenched in history, dogma, and the politics of the post-independence period. Also, it has been argued that the prevailing attitudes and issues in the region are partly connected with the fact that policymakers in the region are not persuaded that the potential benefit of FDI could be fully realized. In view of the above, this study seeks to examineFDI and the effects on the performance of three key subsectors namely oil and refining, cement and other manufacturing companies in Nigeria. 


\section{Review of Related Literature \\ Exploring Foreign Direct Investments}

Foreign Direct Investment (FDI) constitutes a significant component of capital flows across country. According to Thrilwall (1994), FDI refers to direct investments in buildings, technologies, equipment and machineries belonging to the firm of a host country. FID involves not only a transfer of funds (including the reinvestment of profits) but also a whole package of physical capital, techniques of production, managerial and marketing expertise, products advertising and business practices for the maximization of global profits (Korna, Ajekwe \& Idyu, 2013). The Organization of Economic Cooperation and Development (OECD, 2011) sees FDI as the net financing by an entity in a developed country, which has the objective of obtaining or retaining a lasting interest in an entity resident in a developing country. The idea of a lasting interest indicates a long term association in which the investors that is directly involve has important influence on the management of the firm indicated by ownership of at least 10 percent of the shares of the enterprises, or equivalent in voting power or other means of control (Ezeanyeji \& Ifebi, 2016).

In the view of Baltagi, Badi, Bresson \& Pirotte (2006), FDI can be seen as one of the most dynamic phenomena in the recent wave of globalization. There is a vast pool of literature on foreign trade and investment dating as far back as the Smithian era during the 70s (Okoli \& Agu, 2015). While the mercantile economic system propagated hoarding and a close economy, the Smithian economic system was known for its proposition of the free trade and open market system (Adelopo, Omoteso \& Obalola, 2010). The contention for FDI also develop due to the traditional Neo Classical as well as new growth theories. (Ebekozien, Ugochukwu \& Okoye, 2015). For instance, the neo-classical believe that free trade and investment enhance the accumulation of capital stock, provided that adequate consideration is given to factor prices and technology.

OECD 2011, views FDI as a significant part of an open international economic as well as a major component of development. It sees investment made to acquire a lasting management interest (usually $10 \%$ of voting stock) as well as having at least $10 \%$ of equity share in a firms that exist in any country. Mwilima (2003) opines that it can take the form of either 'green-field' investment (also called 'mortar and brick' investment) or merger and acquisition (M\&A), depending on whether the investment is mainly on newly created asset or on only transfers from local to foreign firms.

Adelopo, Omoteso \& Obalola (2010) posit that FDI involves the mobilization of investment funds from foreign investors into the host nation and it usually takes the nation of ownership transfer from local to foreign investors or in terms expansion in the capacity of production and capital accumulation in a country. In the view of Adeleke, Olowe \& Fasesin (2014), FDI is an investment in real assets; where real assets consist of physical elements such as factories, land, capital goods, infrastructure and inventories. FDI is also observed as the engine of growth because it provide the needed capital for investment, improves competition in the host nation as well as support local firms to become more productive by adopting more efficient technology or by investing in human and/or physical capital (Ajayi, 2006a).

FDI may also be seen as any form of investment that earns interest in enterprise which functions outside the domestic territory of the investor (Kamaraj, 2008). It needs a business connection between parent and its foreign subsidiary firm. A foreign direct business of this nature results in multinational corporations and makes an investment to be classified as FDI, in addition the parent firm needs at least $10 \%$ of ordinary shares in its foreign affiliate at least 10 percent of the ordinary shares of its foreign affiliates (Korna, Ajekwe \& Idyu, 2013). Investing firms can also qualify as an FDI if it has voting power in the enterprise that is operating outsider its own country. FDI works as a means of integrating under developed countries into the global market and raising capital availability for investment (Ajayi, 2006).

FDI is also seen to be investment that consists of long-term relation which also reflect a lasting interest which is control by a resident entity in economy other than that of other economies. It indicates that the investors exact a major influence on the management of the business resident in other country. FDI may equally be undertaken by individuals and business entities (UNCTAD, 2008). The modest levels of, and differences in, distribution FDI inflows are due to factors that include deficient regulatory framework, a flawed business environment and opportunities, wrong FDI policies and incentive, weak institutional framework, little market access, unpleasant comparative cost as well as political instability.

In recognizing the merits of FDI, the Nigerian government adopted several policies to attract FDI into the Nigerian economy. More specifically, the government implemented IMF tailored liberalization of its economy, received foreign investors in the manufacturing subsector and grant incentives for equity ownership in all industries except key industry like military equipment (Udoh \& Egwaikhide, 2008; Dinda, 2009; and OECD, 2011). Dictionary of Management defines FDI as an investment in a foreign nation via the acquisition of a local enterprise or establishment of an operation on a new site. Put differently, FDI connote capital inflow from a foreign country that enhance the production capacity of the host economy.

Furthermore, Caves (2007) notes that FDI is the investors made outside its home country. It is the flow of long-term capital based on long-term profit consideration involved in international production Okejiri (2003) 
observes that FDI occurs when an investment located in the home country acquires asset in the host country with the intention of managing that asset. FDI is a two-way flow in that it has two sets of interest: interest of the foreign investor and that of the host country. World Bank 1997 noted that domestic and as well as international structural forces have been driving direct investment to developed nations since the early 1990s.

In industrial countries, the primary forces revolved around the search for higher returns, and opportunities for risk diversification while looking out for higher returns as well as avenues to diversify their risk at home. Two major development in the developed countries enhance the desire of foreign investors to look outward. First, competition and rising cost in domestic markets along with falling transport and communication cost encouraged foreign firms to look for opportunities to increase returns (that is profits) by producing abroad; second, the need to transform financial markets to a more globally integrated market that can attract foreign investors. This occurs due to mutual reinforcement process of advances in information communication as well as financial market.

In emerging country, appropriate environment for FDI has equally been established. Since the mid-1980s, a lot of countries have embarked on structural reform programs leading to increased openness of their economies. Some of the reforms encompass the liberal lowering of obstacles to trade and foreign investment; liberalization of domestic financial markets and restrictions removals on capital movement and privatization programs implementation. This has gone a long way in strengthening the relevance of the private sector as well as industrial progress.

\section{Types of Foreign Direct Investments \\ a. Market-Seeking FDIs}

Market-seeking FDI projects are embarked upon so as to serve local or regional demand. Such FDI projects may be aimed towards markets presently served by exports as well as towards new national or regional markets (Ekstrom, 1998). Market size and prospects for market growth, the desire to stay close to customers, high transportation cost, unfavorable exchange rates and obstacles to trade are all dynamics that affect firms to serve national or regional demand via local production. The motive for market-seeking FDI projects may be elucidated by the comparative production and transaction costs of servicing markets via export or local productions. Especially, economies of scale, trade barriers, transportation costs and exchange rates may affect the trade-off between foreign and export productions.

In other words, "the choice between production and exports depends upon whether the benefits of economies of scale exceed the costs of export induced by trade barriers, transportation costs, exchange rates or other disadvantages of not being a local producer" (Ekstrom, 1998). In general, firms with low scale of plantlevel economies of scale that experience high transportation costs are more disposed to undertake marketseeking FDI projects than other firms are, and vice-versa. In particular, firms in nations with comparatively small market sizes are driven to undertake market-seeking FDIs so as to enlarge and decrease their dependency on the small domestic market (Ekstrom 1998). Investing firms are motivated by the opportunity to capitalize upon their established advantages by undertaking market-seeking FDI projects (cited in Ekstrom).

\section{b. $\quad$ Resource-Seeking FDIs}

The idea of resource-seeking FDI projects is to utilize the comparative advantages of individual countries. This means that firms can apportion production resources in countries where factor prices are relatively low to the firms' productivity. Another important advantage may be the access to raw materials, parts and components (Ekstrom, 1998).

Dunning (1995) recognizes three main types of resource-seekers. There are those seeking physical resources of one kind or another. These firms are driven by the reasons of security of supply and cost minimization. In addition, primary producers and manufacturing firms, from both developed and developing countries, which seek resources like raw materials and minerals can be classified into this group.

The second category is seeking supplies of cheap and well-driven unskilled and semi-skilled labour. Manufacturing and service firms from nations with relatively high real labour costs often undertake this kind of resource-seeking FDI. To supply labour intensive intermediate or final products for export, these firms' setup or at most times acquire affiliates in countries with lower real labour costs. This kind of activity appears usually in the more advanced industrializing developing countries. The last type of resource-seeking FDI is driven by the desire of firms to acquire technological capability, management, organizational skills or marketing know-how.

\section{c. Knowledge-Seeking FDIs}

Knowledge-seeking FDI projects are embarked upon in order to maintain or grow a better competitive position in specific product or geographical markets. This competitive situation can be realized by technological knowledge acquisition and capabilities and/or management expertise.

Dunning (1995) grouped the acquisitions of new technology or capabilities as resource-seeking motives. However, there is an essential dissimilarity between advantages motivating FDI projects tailored towards acquiring technological capabilities and management expertise as well as those advantages connected with 
establishing a firm in locations with favourable factor endowments. While knowledge-seeking FDIs are tailored to acquire new advantages, resource-seeking FDI projects are primarily designed to internalize new location advantages (cited in Ekstrom, 1998).

\section{d. Efficiency-Seeking FDIs}

The aim of efficiency-seeking FDI projects is to downsize the structure of already established production units in such a way that a firm can benefit from the common governance of economic activities in diverse locations (Dunning, 1995). Efficiency-seeking FDI projects tend to arise in capital or technology intensive sectors in which the advantages of intra-industry and intra-firm trade are the largely predominant. Firms in these sectors are inclined to differentiate their products and services as a form of competitive advantage. Potential benefits such as economies of scale and scope can be obtained from product and geographical concentration as well as from process specialization.

To capture the advantages of process specialization means that diverse stages of the value-added chain are concentrated to diverse countries. The advantage of this is that each activity is located in the country providing the lowest marginal cost of production for that particular activity. In this way firms can exploit different factor endowments among various locations as well as they can exploit the scale economies in vertical integration (Ekstrom, 1998).

In efficiency-seeking FDI projects, the advantages of exploiting economies of scale and scope preponderate over the essentials of relative factor endowments across countries. Efficiency-seeking investments according to Dunning (1995) are usually undertaken in countries with largely similar income levels and economic structures. It is fundamental therefore to distinguish between efficiency-seeking and resource-seeking FDI projects. While resource-seeking FDIs are tailored to internalize new locational advantages, efficiency-seeking FDIs are tailored to change a firm's portfolio of locational advantages in order to capture the transaction cost minimizing advantages of a common governance of inter-related activities in diverse locations (Ekstrom, 1998).

\section{e. $\quad$ Risk Reduction-Seeking FDIs}

Risk reduction-seeking FDI projects are tailored to cut down the corporate risk linked with unfavourable variation in macroeconomic variables, variation in supply and demand among national markets and moves of competitors and of national and regional governments. These FDIs signify internal hedging activities conducted in order to cut down the level of corporate risk. Minimizing the firm's exchange rate exposure is an essential goal for risk reduction-seeking FDIs. For example, firms may handle exchange rate risk by stirring production from unfavourable to favourable levels.

Furthermore, because of the supply and demand fluctuations among national markets, firms may undertake FDI projects tailored to diversify the market risk by partaking in production at multiple levels. Another way for firms to cut down risk is to partake in FDI projects that are tailored to widen the product-line. Firms may also partake in FDI projects due to the risks connected with the actual or potential moves of competitors. The purpose of the project could be to prevent competitors from exploiting new profit opportunities as well as to create better opportunities for responding to competitors in the future (Ekstrom, 1998).

\section{Foreign Direct Investments and Performance of Oil and Refining Companies}

Foreign direct investment (FDI) comprise of direct investment in buildings, technologies, equipment and machineries belonging to the firm of a host country. In Nigeria, FDI is strongly enhanced so as to help achieve sustainable economic growth, improved employment conditions, accelerated modernization and raising standard of living. FDI is measured as the net inflows FDI expressed as a share of Gross Domestic Product (GDP). Prior studies (Adeyi, 2017; Adegboye, Adewale \& Ogunrinola, 2016; Ekienabor, Aguwamba \& Liman; 2016; and Adeleke, Olowe \& Fasesin, 2014) suggest that FDI positively and significantly impacts on the performance of oil and refining subsector.

A study by Adeyi (2017) on the effect of foreign direct investment and the performance of oil and refining subsector in Nigeria established that FDI is significant at 5\% and positively related to manufacturing sector capacity utilization (MCU). Besides, the variance decomposition result and that of impulse response function revealed a connection between FDI and the performance oil and refining companies. Similarly, Adegboye, Adewale \& Ogunrinola (2016) assessed how the flow of FDI has impacted on the performance of oil and refining companies in Nigeria. The findings indicated that FDI is statistically significant in connection with the performance of oil and refining companies but dissatisfying such that the likely anticipated features of performance, like investment, technology transfer, increased domestic savings, and increased domestic productivity which will result into diminution of high level of import have not been realized.

Contrarily, extant literature in both developed and developing countries (Azeroual, 2016; Orji, Onyinye, Nchege \& Okafor, 2015; Iddrisu, Adam \& Halidu, 2015; and Nwosa \& Amassoma, 2014) suggest that FDI negatively affects the performance of oil and refining companies. For instance, Azeroual (2016) found that FDI negatively affects the performance of oil and refining companies in Morocco. In the same vein, a study by Iddrisu, Adam \&Halidu (2015) found that FDI negatively affect the productivity of the manufacturing sector in 
Ghana. Similar results of a study conducted by Nwosa \& Amassoma (2014) in Nigeria revealed that FDI has negative impact on the performance of oil and refining companies.

Given the fact the nature of the contradictory results of prior studies as regards FDI and the performance of oil and refining companies, there is the need to conduct an investigation so as to support or refute the results of prior studies, hence the inclusion of FDI and performance measure of oil and refining companies in the model of our study. Thus, it was hypothesized that there is no significant association between foreign direct investments and the performance of oil and refining companies in Nigeria.

\section{Foreign Direct Investments and Performance of Cement Companies}

In Nigeria, cement companies form a major component of the manufacturing sector since it contributes significantly to FDI as well as the growth of the economy (GDP). More importantly is the fact that while studies on FDI and the performance of cement companies show conflicting findings (Adeyi, 2017; Adegboye, Adewale \& Ogunrinola, 2016; and Ekienabor, Aguwamba \& Liman; 2016) i.e. positive effect of FDI on the performance of cement companies, there are other studies (Azeroual, 2016; Iddrisu, Adam \&Halidu, 2015; and Nwosa \& Amassoma, 2014) suggesting that there is negative effect of FDI on the performance of cement companies in Nigeria.

First, Adeyi (2017) examined the effect of foreign direct investment on the manufacturing subsector performance in Nigeria by focusing on one major components of the sector - cement companies. Findings showed that FDI significantly and positively affect cement companies. In the view of Adegboye, Adewale \& Ogunrinola (2016) it was found that the flow of FDI has affected the cement companies' performance in Nigeria. The findings indicated that FDI is statistically significant in connection with performance of cement companies.

Second, extant literature suggests that FDI negatively affects the performance of cement companies. For instance, Azeroual (2016) found that FDI negatively influence the performance of cement companies while a study by Iddrisu, Adam \& Halidu (2015) found that FDI negatively affect the productivity of cement companies in Ghana. Similar results of a study conducted by Nwosa \& Amassoma (2014) in Nigeria and it was shown that FDI has negative impact on cement companies' performance.

Given the fact the nature of the contradictory results of prior studies as regards FDI and cement companies' performance, there is the need to carry out an investigation so as to support or refute the results of prior studies, hence the inclusion of FDI and performance measure of cement companies in the model of our study. Thus, it was hypothesized that there is no significant association between foreign direct investments and cement companies' performance in Nigeria.

\section{Foreign Direct Investments and Performance of Other Manufacturing Companies}

In the Nigerian environment, the manufacturing sector is classified as oil and refining, cement companies and other manufacturing companies which no doubt is composed of companies in the consumer goods subsector. Thus, other manufacturing companies as classified by the Central Bank of Nigeria (CBN) form a major constituent of the manufacturing sector since it contributes significantly to FDI as well as the growth of the Nigerian economy. More importantly is the fact that while studies on FDI and other manufacturing companies' performance show conflicting findings (Adeyi, 2017; Adegboye, Adewale \& Ogunrinola, 2016; and Ekienabor, Aguwamba \& Liman; 2016) i.e. positive effect of FDI on other manufacturing companies' performance, there are other studies (Azeroual, 2016; Iddrisu, Adam \&Halidu, 2015; and Nwosa \& Amassoma, 2014) suggesting that there is negative influence of FDI on other manufacturing companies' performance in Nigeria.

First, Adeyi (2017) assessed the impact of FDI on the manufacturing subsector performance in Nigeria by focusing on one major components of the sector-consumer goods companies found that FDI has a significant and positive effect on consumer goods companies. In the view of Adegboye, Adewale \& Ogunrinola (2016) it was found that the flow of FDI has impacted on the consumer goods companies' performance in Nigeria. The findings indicated that FDI is statistically significantly in relation to consumer goods companies' performance.

Second, extant literature suggests that FDI negatively affects the consumer goods companies' performance. For instance, Azeroual (2016) found that FDI negatively affects the consumer goods companies' performance while a study by Iddrisu, Adam \& Halidu (2015) found that FDI negatively influence the productivity of consumer goods companies in Ghana. Similar results of a study conducted by Nwosa \& Amassoma (2014) shown that FDI has negatively affected the consumer goods companies' performance in Nigeria.

Given the fact the nature of the contradictory results of prior studies as regards FDI and the consumer goods companies' performance (other manufacturing companies), there is the desire to carry out an investigation so as to refute or support the outcomes of prior studies, hence the inclusion of FDI and performance measure of other manufacturing companies in the model of our study. Thus, it was hypothesized that there is no significant connection between foreign direct investments and other manufacturing companies' performance in Nigeria. 


\section{Theoretical Framework}

In this paper, the theoretical framework is premised on the Neo-classical growth theory. In the neo-classical growth literature, foreign direct investments are associated positively with output growth because it either intensifies the volume of investment and/or its efficiency or thus puts the economy on a higher long-term path of growth. Thus, foreign direct investments can have a level effect and apart from the potential efficiency increase, there is no qualitative difference to domestic capital in the neo-classical theory. Turning towards endogenous growth paradigm, the potential role of foreign investment is much more-greater. Foreign investment may affect each argument in the production grid and have additional indirect effect as well as permanent effects on growth rate. Again, foreign direct investment can impact on the stock of capital available in the country.

In the course of raising capital for instance, the number of varieties for intermediate goods or capital equipment, foreign investment can increase productivity (Borensztein, 1998). In addition, foreign direct investment can permanently increase the growth rate through spillovers and the transfer and diffusion of technologies, ideas, management and production processes, etc. These are basically the four channels which allow for technological spillovers from foreign investment on the host economy (Kinoshita, 2001)

\section{Empirical Studies}

Conceivably, the fundamental role played by foreign direct investment (FDI) may have propelled studies on FDI and manufacturing subsector performance in both developed and developing nations. For instance, Adeyi (2017) investigated the effect of FDI on the manufacturing subsector performance in Nigeria and the nexus between FDI and manufacturing capacity utilization (MCU) spanning 1970-2012 by means of VAR statistical tool. The cointegration result revealed that there is no long-run link among the variables. In addition, findings showed that FDI is significant at 5\% and positively related to MCU. On the other hand, other variables are not significant and both EXR and INT exhibit wrong a-priori signs.

Adegboye, Adewale \& Ogunrinola (2016) assessed how the flow of FDI to the African region has impacted on the industrial performance of the regions, using the proxy of industrial added valued. Pooled data from fortythree African countries within the period of 1996 to 2015 were obtained and analysis of data was based on the OLS. The findings indicated that FDI is statistically significantly in explaining the industrial performance of host African nations but not satisfying.

In Nigeria, Ehijiele, Sunday \& Nuruddeen (2016) investigated the effect of FDI on the manufacturing subsector performance by means of econometric method to analyze the data. OLS was applied in investigating the relationships between FDI and manufacturing subsector output and exchange rate. The study revealed a positive connection between FDI, exchange rates and manufacturing output.

Okoli \& Agu (2015) examined the impact of FDI flow and the manufacturing subsector performance in Nigeria. The study used time-series data from CBN statistical bulletin for a period of 40years. OLS technique was used and result suggests a positive and long-run connection between FDI and manufacturing subsector performance in Nigeria.

A study by Iddrisu, Adam \& Halidu (2015) on effect of FDI on productivity of the industrial sector in Ghana showed that FDI, gross fixed capital formation and trade openness exert significant long-run positive influence on productivity of the industrial sector. Besides, it was found that exchange rate exerts significant negative influence on industrial sector productivity in the long-run in Ghana. The study period covered $1980-$ 2013 and Johansen cointegration test was used in estimating the model of the study.

In China, Chan (2014) investigated the nature of FDI and the manufacturing sector performance during 1985-2010. Using panel data and OLS tool, the study found that FDI significantly impact on the manufacturing sector performance in China. Besides, it was revealed that China's rise in FDI does not pose a threat to neighboring East Asian countries.

Bakari, Chamalwa \& Jackson (2013) assessed the determinants of FDI inflows in Nigeria manufacturing subsector. The study period spanned 1970-2010 and OLS tool was used in the analysis. The study found a correlation between FDI inflows and the manufacturing subsector performance in Nigeria.

In India, Preeya \& Patrick (2012) studied the association between FDI flows and the manufacturing sector performance between 1990-2010. The Hausman-Taylor statistical test was conducted on the data obtained and the study found that both host and destination nations play a fundamental role in FDI flows, thus affecting the performance of the manufacturing sector in India.

In Asia, Kavita \& Sudhakara (2011) examined how FDI contributes to the manufacturing sector performance using some selected Asian countries during the period 1991-2008. Using panel data from ten (10) Asian countries, the results showed that FDI have a significant impact on the manufacturing sector performance in all the ten (10) Asian countries.

\section{Research Methods}

This paper examined foreign direct investments and the effects on the performance of three key subsectors 
namely oil and refining, cement and other manufacturing companies in Nigeria. In view of this, ex-post facto research designwas employed and data of foreign direct investment (FDI), contributions of oil and refining, cement and other manufacturing companies' to Gross Domestic Product (GDP) were obtained as measures of manufacturing subsector performance while average manufacturing capacity utilization (AMCU) as he moderating variable. Data were obtained from Central Bank of Nigeria (CBN) Statistical Bulletin and World Bank Development Indicators spanning the period 1981 to 2016. In line with this, the model was formulated as follows:

\begin{tabular}{|c|c|c|c|c|}
\hline$M O R$ & $=$ & $F(F D I, A M U)$ & - & - \\
\hline$M C E$ & $=$ & $F(F D I, A M U)$ & - & - \\
\hline$O M Q$ & $=$ & $F(F D I, A M U)$ & - & - \\
\hline
\end{tabular}

In line with equations 1-3, equations 3-6 were estimated in their linearly form(s):

\begin{tabular}{|c|c|c|c|c|}
\hline & $=$ & $b_{o}+b_{1} F D I+b_{2} A M U+u t$ & - & - \\
\hline I & $=$ & $b_{o}+b_{1} F D I+b_{2} A M U+u t$ & - & - \\
\hline$O M Q$ & $=$ & $b_{o}+b_{1} F D I+b_{2} A M U+u t$ & - & - \\
\hline
\end{tabular}

Where: $M C E=$ Cement (Industrial) Firms contribution to GDP; $O M Q=$ Other Manufacturing Firms contribution to GDP;MOR= Oil and Refining Firms contribution to GDP (a measure of manufacturing subsector performance) $F D I=\quad$ Foreign Direct Investments (a measure of foreign investment proxied as investment made by an individual or firm in another country known as the 'host nation' via formation of a company or acquisition of business assets.); $A M U=$ Average Manufacturing Capacity Utilization (a control variable); $u_{t}=$ Error term; $\beta_{1}, \& \beta_{2} \quad=$ Parameters to be estimated. The statistical testsconducted are stationarity and unit root, co-integration, parsimonious Error Correction Modeland granger causality tests via E-Views.

\section{Empirical Results and Discussion}

Table 1: Result of Descriptive Statistics

\begin{tabular}{lccccc}
\hline & LMOR & LOMQ & LMCE & LAMU & LFDI \\
Mean & 2.006353 & 2.804242 & 3.252165 & 3.926884 & 4.524714 \\
Median & 2.232381 & 3.027448 & 3.134092 & 3.770417 & 4.617478 \\
Maximum & 6.021751 & 6.074196 & 6.619980 & 8.616676 & 9.305651 \\
Minimum & -2.995732 & -0.072571 & -0.494296 & 3.377246 & -0.306797 \\
Std. Dev. & 3.115579 & 1.963531 & 1.872757 & 0.857779 & 2.738093 \\
Skewness & -0.238382 & -0.021024 & 0.032629 & 4.988308 & 0.133524 \\
Kurtosis & 1.620626 & 1.787250 & 2.195127 & 27.92063 & 1.891536 \\
Jarque-Bera & 3.017465 & 2.086085 & 0.923779 & 1020.808 & 1.841678 \\
Probability & 0.221190 & 0.352381 & 0.630092 & 0.000000 & 0.398185 \\
Sum & 68.21601 & 95.34424 & 110.5736 & 133.5140 & 153.8403 \\
Sum Sq. Dev. & 320.3256 & 127.2299 & 115.7382 & 24.28091 & 247.4061 \\
\hline
\end{tabular}

Source: Authors Computation (2019) via E-views 9

The average value for MOR is 2.01 while the standard deviation is 3.23. The highest value for MOR is 6.02 while the minimum value is -2.10 . The mean for OMQ is 2.80 while the standard deviation is 1.96 . The highest and lowest values for OMQ are 6.07 and -0.07 . The mean and standard deviation for MCE are 3.25 and 1.87 respectively. The highest value is 6.62 while the minimum value is -0.49 . The mean for AMU is 3.93 and the standard deviation is 3.38. The maximum value is 8.62 while the minimum value is 3.38 . The mean for FDI is 4.52 while the standard deviation is 2.74 . The highest and lowest values are 9.31 and -0.31 . The skewness values are greater than 0 in most cases, indicating that the series is skewed to right and that the series has a longright tail. Besides, the Jarque-bera normality test result shows that the residuals are conventionally distributed in most of the period.

Table 2: Result of Correlation Analysis

\begin{tabular}{clllll}
\hline & LMOR & LOMQ & LMCE & LAMU & LFDI \\
LMOR & 1 & & & & \\
LOMQ & 0.478302772 & 1 & & & \\
LMCE & 0.357176547 & 0.174168270 & 1 & & \\
LAMU & 0.248087107 & 0.213741263 & 0.251322127 & 1 & 1 \\
LFDI & 0.452087192 & 0.244431933 & 0.320631075 & 0.354039791 & 1 \\
\hline
\end{tabular}

Source: Authors Computation (2019) via E-views 9

The result of the inter-correlation did not show high correlation. Thus, on the average the correlation result imply the absence of multicollinearity since none of the values was so close to 1 or exceeded 0.8 . 
Table 3: Summary of ADF Unit Root Test Result

\begin{tabular}{|lccc|}
\multicolumn{1}{c}{ Variables } & Level Data & First Difference & Order of Integration \\
\hline LOMQ & -0.064 & $-3.76^{*}$ & $\mathrm{I}(1)$ \\
\hline LMOR & -0.99 & $-4.32^{*}$ & $\mathrm{I}(1)$ \\
\hline LMCE & -0.31 & $-5.84^{*}$ & $\mathrm{I}(1)$ \\
\hline LFDI & -0.96 & $-7.85^{*}$ & $\mathrm{I}(1)$ \\
\hline LAMU & -1.12 & $-9.67^{*}$ & $\mathrm{I}(1)$ \\
\hline
\end{tabular}

Source: Authors Computation (2019) via E-views 9 *Indicates stationary at the 1 percent level; 1 percent critical value -3.65; I(1) integrated of order 1 .

The ADF unit root test result indicates that the variables were originally non stationary. They however became stationary when they were subjected to first differencing, the dependent, independent and control variables were all stationary at the 1 percent level. They are thus said to be integrated of order 1 or I(1).

Table 4: Summary of OLS Result for the Three Models

\begin{tabular}{|llll|}
\multicolumn{1}{c}{ Independent Variables } & \multicolumn{3}{c|}{ EQUATIONS/DEPENDENT VARIABLES } \\
\cline { 2 - 4 } & $1 \mathrm{LMCE}$ & 2 LMOR & 3 LOMQ \\
\hline LFDI & 0.08 & 0.51 & 0.37 \\
& 1.25 & 3.78 & 3.95 \\
& $(0.2219)$ & $(0.0007)$ & $(0.0004)$ \\
\hline LAMU & 0.06 & 0.17 & 0.01 \\
& 0.33 & 0.89 & 0.14 \\
& $(0.7404)$ & $(0.3779)$ & $(0.8934)$ \\
\hline $\mathbf{R}^{\mathbf{2}}$ & 0.88 & 0.86 & 0.84 \\
\hline $\mathbf{D W}$ & 2.27 & 2.11 & 2.29 \\
\hline $\mathbf{t}$ critical & 1.68 & 1.68 & 1.68 \\
\hline
\end{tabular}

Source: Authors Computation (2019) via E-views 9; Figures in parenthesis are probabilities

The $\mathrm{R}^{2}$ which is the coefficient of determination indicate that 88 percent of the total variation in the MCE has been explained by the FDI and AMU taken together. This is a good fit since the unexplained variation is just $12 \%$. The FDI and AMU have positive relationship with the MCE. An increase in the FDI and AMU by 1 unit each increase the MCE by $0.37,0.47$ and 0.06 units. The result shows further that the FDI, with t-statistic of 1.25 is not significant in explaining the changes in the MCE. The non-significance of the AMU provides an indication of underutilization of the manufacturing capacity in cement production in Nigeria. The DW of 2.27 indicate the absence of serial correlation.

The result in equation 2 indicates that 86 percent of the total variation in the MOR has been explained by the FDI and AMU taken together. This is a good fit since the unexplained variation is 14 percent. The result indicates that the FDI and AMU have positive relationship with MOR. An increase in the FDI and AMU by 1 unit each increased the MOR by $0.51,1.02$ and 0.17 unit. The result indicates that the FDI with t-values of 3.78 and probability of 0.0007 is statistically significant in explaining the changes in the MOR. The non-significance of the AMU is an indication that capacity in oil refining is underutilized. The Durbin Watson (DW) of 2.11 indicates no serial correlation in the model.

The result in equation 3 indicates that 84 percent of the total variation in the OMQ has been explained by the FDI and AMU taken together. This is a good fit since the variation explained outside the model is only 16 percent. The FDI and AMU have a positive relationship with the OMQ. An increase in the FDI and AMU by 1 unit each increased the OMQ by $0.37,0.56$ and 0.01 units respectively. The result shows further that the FDI with t-value of 3.95 and probability of 0.0004 is statistically significant in explaining the changes in OMQ. The DW of 2.29 indicates the absence of serial correlation. 
Table 5:Summary of Johansen Cointegration Test Result

\begin{tabular}{cccc}
\hline \hline $\begin{array}{c}\text { Hypothesized } \\
\text { No. of CE(s) }\end{array}$ & $\begin{array}{c}\text { Trace } \\
\text { Statistic }\end{array}$ & $\begin{array}{c}0.05 \\
\text { Critical Value }\end{array}$ & Prob.** \\
\hline \hline None * & 402.9215 & 159.5297 & 0.0000 \\
At most 1 $*$ & 173.1490 & 95.75366 & 0.0000 \\
At most 1 & 113.1432 & 69.81889 & 0.0000 \\
At most 2 & 60.94796 & 47.85613 & 0.0019 \\
At most 4 & 24.91809 & 29.79707 & 0.1644 \\
& MAX-EIGEN & & \\
None * & 129.5257 & 52.36261 & 0.0000 \\
At most 1 & 60.00572 & 40.07757 & 0.0001 \\
At most 2 & 52.19527 & 33.87687 & 0.0001 \\
At most 3* & 36.02987 & 27.58434 & 0.0033 \\
At most 4 & 17.28929 & 21.13162 & 0.1588
\end{tabular}

Source: Authors Computation (2019) via E-views 9

The Johansen co-integration test result indicates the existence of a long run equilibrium nexus among the variables.

Table 6: Summary of Overparameterized ECM Result for the Three Equations

\begin{tabular}{|l|l|l|l|}
\hline \multirow{2}{*}{ INDEPENDENT VARIABLES } & \multicolumn{3}{|c|}{ EQUATIONS/DEPENDENT VARIABLES } \\
\cline { 2 - 4 } & $\mathbf{( 1 )}$ LMCE & (2)LMOR & \multicolumn{1}{c|}{ (3)LOMQ } \\
\hline LFDI & -0.03 & 0.42 & 0.21 \\
& -0.15 & 2.05 & 1.95 \\
& $(0.8809)$ & $(0.0525)$ & $(0.0637)$ \\
\hline LFDI (-1) & 1.68 & -0.10 & 0.91 \\
& 4.35 & -0.49 & 2.68 \\
& $(0.0003)$ & $(0.6288)$ & $(0.0139)$ \\
\hline LFDI(-2) & 0.11 & 0.03 & 0.15 \\
& 0.70 & 0.19 & 1.84 \\
& $(0.4891)$ & $(0.8506)$ & $(0.0794)$ \\
\hline LAMU & 0.30 & -0.002 & 0.34 \\
& 0.98 & -0.005 & 3.86 \\
& $(0.3397)$ & $(0.9959)$ & $(0.0006)$ \\
\hline LAMU(-1) & 0.39 & -0.27 & 0.22 \\
& 2.81 & -0.82 & 1.29 \\
& $(0.0109)$ & $(0.4211)$ & $(0.2099)$ \\
\hline LAMU(-2) & 0.14 & 0.34 & 0.01 \\
& 0.58 & 1.45 & 0.06 \\
\hline ECM(-1) & $(0.5661)$ & $(0.16)$ & $(0.9553)$ \\
\hline t-critical & -0.71 & -0.22 & -0.39 \\
\hline AIC & -8.20 & -3.59 & -3.21 \\
\hline DC & $(0.000)$ & $(0.0013)$ & $(0.0041)$ \\
\hline & 0.91 & 0.86 & 0.97 \\
\hline & 2.18 & 2.41 & 1.09 \\
\hline & 2.68 & 2.40 & 1.59 \\
\hline & 1.99 & 2.03 & 2.14 \\
\hline & 1.68 & 1.68 & 1.68 \\
\hline
\end{tabular}

Source: Authors Computation (2019) via E-views 9; Figure in parentheses are probabilities

The parsimonious ECM used for policy purpose was obtained by deleting the insignificant variables from the overparameterized ECM and the model is then estimated. The result of the parsimonious ECM is shown below: 
Table 7: Result of Parsimonious ECM for the Three Equations

\begin{tabular}{|c|c|c|c|}
\hline \multirow[t]{2}{*}{ INDEPENDENT VARIABLES } & \multicolumn{3}{|c|}{ EQUATIONS/DEPENDENT VARIABLES } \\
\hline & (1) LMCE & (2) LMOR & (3)LOMQ \\
\hline LFDI & & $\begin{array}{l}0.52 \\
3.28 \\
(0.0028) \\
\end{array}$ & \\
\hline LFDI (-1) & $\begin{array}{l}0.38 \\
1.41 \\
(0.1743) \\
\end{array}$ & & $\begin{array}{l}0.40 \\
6.74 \\
(0.0000)\end{array}$ \\
\hline LAMU & & $\begin{array}{l}0.12 \\
0.69 \\
(0.4946)\end{array}$ & $\begin{array}{l}0.34 \\
3.76 \\
(0.0008)\end{array}$ \\
\hline LAMU(-1) & $\begin{array}{l}0.07 \\
0.53 \\
(0.6032)\end{array}$ & & \\
\hline ECM(-1) & $\begin{array}{l}-0.26 \\
-5.45 \\
(0.0001) \\
\end{array}$ & $\begin{array}{l}-0.29 \\
-3.59 \\
(0.0013) \\
\end{array}$ & $\begin{array}{l}-0.37 \\
-2.83 \\
(0.0085) \\
\end{array}$ \\
\hline $\mathbf{R}^{2}$ & 0.91 & 0.84 & 0.86 \\
\hline AIC & -1.90 & -2.46 & -1.14 \\
\hline SC & -2.12 & -2.69 & -1.37 \\
\hline DW & 2.17 & 2.27 & 2.16 \\
\hline t-critical & 1.68 & 1.68 & 1.68 \\
\hline
\end{tabular}

Source: Authors Computation (2019) via E-views 9; Figure in parentheses are probabilities

The result of parsimonious ECM for the equation indicates that 91 percent of the total changes in the MCE have been explained by the FDI and AMU taken together. It is a good fit because only 9 percent of the changes were explained outside the model. The result indicates that FDI and AMU have a positive relationship with the MCE. An increase in the FDI and AMU by 1 unit each increases the MCE by 0.38 and 0.07 units. The result shows that FDI and AMU was not statistically significant in explaining the changes in the MCE. This is an indication that the inflow of FDI into the Nigeria cement industry has not been satisfactory. The result also indicates an under-utilization of manufacturing capacity in the cement industry.

Furthermore, the result for the equation indicates that 84 percent of the total variation in the MOR has been explained by the FDI and AMU taken together. This is a good fit since only 16 percent of the variation was explained outside the model. The result shows that the FDI and AMU have positive relationship with the MOR. An increase in the FDI and AMU by a unit each increased the MOR by 0.52 and 0.12 units. The result indicates further that the FDI was statistically significant in explaining the changes in the MOR. The AMU was not significant indicating an underutilization of manufacturing capacity in oil refining in Nigeria. The result in equation 3 indicates that FDI and AMU have positive impact on the OMQ. An increase in the FDI and AMU by 1 unit each increased the OMQ by 0.40 and 0.34 units. The result indicates further that the one period lag FDI and AMU with t-values of 5.74 and 3.75 and probabilities of 0.0000 and 0.0008 are statistically significant in explaining the changes in the OMQ 
Table 8: Result of Grange Causality at Lag 2

\begin{tabular}{|c|c|c|c|}
\hline Null Hypothesis: & Obs & F-Statistic & Prob. \\
\hline LOMQ does not Granger Cause LMOR & \multirow[t]{2}{*}{34} & 0.21918 & 0.8045 \\
\hline LMOR does not Granger Cause LOMQ & & 2.16004 & 0.1335 \\
\hline LMCE does not Granger Cause LMOR & \multirow[t]{2}{*}{34} & 1.09943 & 0.3465 \\
\hline LMOR does not Granger Cause LMCE & & 1.50617 & 0.2386 \\
\hline LFDI does not Granger Cause LMOR & \multirow[t]{2}{*}{34} & 3.36604 & 0.0485 \\
\hline LMOR does not Granger Cause LFDI & & 7.34754 & 0.0026 \\
\hline LAMU does not Granger Cause LMOR & \multirow[t]{2}{*}{33} & 0.64103 & 0.5343 \\
\hline LMOR does not Granger Cause LAMU & & 1.33987 & 0.2782 \\
\hline LMCE does not Granger Cause LOMQ & \multirow[t]{2}{*}{34} & 0.75103 & 0.4808 \\
\hline LOMQ does not Granger Cause LMCE & & 2.91135 & 0.0704 \\
\hline LFDI does not Granger Cause LOMQ & \multirow[t]{2}{*}{34} & 0.44837 & 0.6430 \\
\hline LOMQ does not Granger Cause LFDI & & 4.11321 & 0.0268 \\
\hline LAMU does not Granger Cause LOMQ & \multirow[t]{2}{*}{33} & 1.68766 & 0.2032 \\
\hline LOMQ does not Granger Cause LAMU & & 1.53319 & 0.2334 \\
\hline LFDI does not Granger Cause LMCE & \multirow[t]{2}{*}{34} & 0.96821 & 0.3917 \\
\hline LMCE does not Granger Cause LFDI & & 5.81515 & 0.0075 \\
\hline LAMU does not Granger Cause LMCE & \multirow[t]{2}{*}{33} & 0.04443 & 0.9566 \\
\hline LMCE does not Granger Cause LAMU & & 1.40024 & 0.2633 \\
\hline LAMU does not Granger Cause LFDI & \multirow[t]{2}{*}{33} & 3.97537 & 0.0302 \\
\hline LFDI does not Granger Cause LAMU & & 4.60211 & 0.0187 \\
\hline
\end{tabular}

Source: Authors Computation (2019) via E-views 9

No causality exists between OMQ and MO, MCE and MOR as well as between FDI and MOR. However, the result shows a bicausal relationship from FDI to MOR and MOR with FDI with probability of 0.0485 and 0.0026. Besides, no causality existsbetween AMU and MO and between MCE and OMQ. The result also shows causality from OMQ to FDI with probability of 0.0268 and not the opposite. The result indicates a bicausal relationship from MCE to FDI with probability of 0.0075 . The result also indicates no causality between AMU and MCE.

\section{Conclusion and Recommendations}

This paper has been on assessing the effect of foreign direct investment on the performance of manufacturing subsector in Nigeria. Co-integration and Error correction models of the ordinary least squares (OLS) techniques were used to analyse the data of the study. The result of descriptive statistics indicates that the variables are well behaved as it indicates that the variables are not closely linked as it shows differences between the mean and their standard deviation. The result of the skewness with values greater than 0 in most of the cases indicates that the series has a long right tail. The Jarque-bera test for normality has probability lower than 5 percent in most cases which indicates that the residuals are normally distributed. The result of the correlation matrix did not show evidence of multicollinearity among the variables. The ADF unit root tests indicates that the variables are originally non stationary, but became stationary after the first difference was taken indicating that the variables are (i) integration of order I.

More importantly, the OLS result indicates that FDI and AMU were not statistically significant in explaining the changes in MOR. Contrarily, it was established that FDI was statistically significant in explaining OMQ. The result overall indicates that policies to attract FDI if well managed could improve the manufacturing subsector performance in Nigeria. On the basis of the above findings, it was recommended that the government should deepen their efforts to open up the manufacturing subsector to foreign direct investments. This will reduce the dominance of a particular company in the sector and further improve the output of the manufacturing 
subsector.

\section{REFERENCES}

Adegboye, F.B., Adewale, J.T. \& Ogunrinola, I. I. (2016). Foreign Direct Investment and industrial performance in Africa. The Social Sciences, 11(24): 5830-5837

Adeleke, K. Olowe, S. \& Fasesin, O. (2014). Impact of foreign direct investment on Nigeria economic growth. International Journal of Academic Research in Business and Social Sciences, 4(8): 33-44

Adelopo, I., Omoteso, K. \& Obalola, M. (2010). Impact of Corporate Governance on Foreign Direct Investment in Nigeria. Leicester Business School, De Montfort University.

Adeyi, F. (2017). Foreign direct investment and the manufacturing sector in Nigeria. Institutional Repository, University of Nigeria, Nsukka. http://hdl.handle.net/123456789/4348

Ajayi, S.I. (2006a). FDI and economic development in African. A Paper Presented at the ADB/AERC International Conference in Accelerating African Development, Tunis. November $22^{\text {nd }}-24^{\text {th }}$.

Ajayi, S.I. (2006b). The determinants of foreign direct investment in Africa: A survey of the evidence. In: Ajayi, S.I. (ed.), Foreign Direct Investment in Sub-Saharan African: Origins, Targets and Potential. AERC, Nairobi.

Akinlo, F. (2006). Foreign direct investment and growth in Nigeria: An empirical investigation. Journal of Policy Modeling, 26(5): 627-639.

Azeroual, M. (2016). The impact of foreign direct investment on the productivity growth in the Moroccan manufacturing sector: Is source of FDI important? Journal of International and Global Economic Studies, 9(1): 29-45

Bakari H.R, Chanalwa H.A \& Jackson S.Y (2013). Determinants of foreign direct investment inflows to Nigeria (1970 - 2010). Journal of Mathematics, 9(1): 77-99

Baltagi, B.H, Badi, H., Bresson, G. \& Pirotte, A. (2006). Joint LM test for homoskelasticity in a one - way error component model. Journal of Economics, 134(2): 1-19

Borensztein, E, (1998). How does foreign direct investment affect economic growth? Journal of International Economics, 45(1): 115-135

Caves, R.E. (2007). Multinational Enterprises and Economic Analysis, (3 ${ }^{\text {rd }}$ edition), London: Cambridge University Press.

CBN (2012). Foreign private investment in Nigeria. Proceedings of the 12thAnnual Conference of the Regional Research Unit Kaduna

Chan, H.S. (2014). The nature of FDI competition in East Asian: Crowding - out crowding - in?. Centre for Economic and Social Studies

Dinda, S. (2009). FACTOR Attracting FDI to Nigeria: An Empirical Investigation. Tamil Nadu India: Madras School of Economics, GandiMandapam Road Kottur, Chennia 600025.

Dunning J. H (1995). The Eclectic Paradigm as an Envelope for Economic and Business Theories of MNE activity. International Business Review 9(2000): 163-190

Ebekozien, A., Ugochukwu, S.C. \& Okoye, P.U. (2015). An analysis of the trends of FDI inflows in the Nigerian construction sector. American International Journal of Contemporary Research, 5(1): 19-33

Ehijiele, E., Sunday, A. \& Nuruddeen, L. (2016). Foreign direct investment and its effect on the manufacturing sector in Nigeria. International Journal of Scientific and Research Publications, 6(5): 1-19

Ekienabor, E., Aguwamba, S. \& Liman, N. (2016). Foreign direct investment and its effect on the manufacturing sector in Nigeria. International Journal of Scientific and Research Publications, 6(5): 671-679

Ezeanyeji, C.I. \& Ifebi, O.L. (2016). Impact of FDI on sectoral performance in the Nigerian economy. International Journal of Humanities Social Sciences and Education, 3(2): 88-109

Iddrisu, A., Adam, B. \& Halidu, B.O. (2015). The Influence of foreign direct investment (FDI) on the productivity of the industrial sector in Ghana. International Journal of Academic Research in Accounting, Finance and Management Sciences, 5(3): 1-13

Kamaraj, C.S. (2008). Foreign direct investment. Institute of Management Studies, Madura, 632022.

Kavita W. \& Sudhakara R.S (2011). Foreign direct investment into developing Asian countries: the role of market seeking, resource seeking and efficiency seeking factor. International Journal of Business and Management, 6(11): 101-123

Kinoshita, Y. (2001). R \& D and technology spillovers through FDI, innovation and absorptive capacity. CEPR Discussion Paper, 2275.

Korna, J.M. Ajekwe, T. \& Idyu, I. (2013). Impact of foreign direct investment on the Nigerian banking sector. Journal of Business and Management, 7(4): 1-19

Mwilima, N. (2003). Foreign Direct Investment in Africa. African Labour Research Network, African Social Observatory Pilot Project: 94.

Nwosa, P.I. \& Amassoma, D. (2014). Capital inflows and exchange rate in Nigeria:. Mediterranean Journal of 
Social Sciences, 5(7): 109-123

OECD, (2011). Benchmark Definition of Foreign Direct Investment. Paris OECD, 4: 34 - 39

Oji, O.L. \& Huang, H. (2016). Analysis on the contribution of FDI on Nigeria manufacturing sector. Proceedings of the 8th International Conference on Innovation and Management.

Okejiri, E. (2003). National Office for Technology Acquisition and Promotion (NOTAP), Speech at Nigeria's Imperative in the New World Trade Order, Workshop Report. African Economic Research Consortium (AERC), Nairobi, Kenya and Trade Policy Research and Training Program (TPRTP). Department of Economics, University of Ibadan: Ibadan.

Okoli T.T \& Agu O.C. (2015). Foreign direct investment flow and manufacturing sector performance in Nigeria. International Journal of Economics, Commerce and Management 3(7): 1-13

Olaseni, D. (2017). Towards recovery of the manufacturing subsector. THISDAY Newspaper, January 15th.

Orji, A., Onyinye, O.I., Nchege, J.E. \& Okafor, J. (2015). Manufacturing output and foreign direct investment in Nigeria: A new evidence. International Journal of Academic Research in Economics and Management Sciences, 4(3): 2226-3624

Preeya S.M \& Patrick K.W (2012). CARICOM foreign direct investment flows. Sir Arthur Lewis Institute of Social and Economic Studies, University of the West Indies

Thrilwall, A.P. (1994). Growth and Development. London: Macmillan.

Udoh, E. \& Egwaikhide, E.O. (2008). Exchange rate volatility, inflation, uncertainty and foreign direct investment in Nigeria. Botswana Journal of Economics, 5(7): 1-15

UNCTAD (2008). World Investment Prospects Survey 2008-2010. New York and Geneva United Nations Publication. 